\title{
Overuse and abuse of cortisone
}

\author{
Kortizonun aşırı ve yanlış kullanımı
}

\author{
O. Şahap Atik, MD. \\ Department of Orthopedics and Traumatology, Medical Faculty of Gazi University, Ankara, Turkey
}

The serious side effects of cortisone are well-known and documented; however, many doctors ignore them. The most common complications faced by orthopedic surgeons are joint infection, tendon weakening or rupture, osteoporosis, deterioration of cartilage within a joint, osteoarthritis, and osteonecrosis. These serious conditions may require major surgeries like arthroplasties. ${ }^{[1]}$

First of all, cortisone is not for all. While the injections help some patients significantly, at least for a period of time, others do not get any relief. Some patients' disease is too far advanced to respond to this approach, or any conservative approach.

For instance, osteoarthritis results from a complex system of interacting mechanical, biological, and biochemical factors. ${ }^{[2]}$ It is a major cause of chronic musculoskeletal pain and dysfunction. There are studies demonstrating discordance between pain and radiograph. ${ }^{[3]}$ Therefore, we must treat the patients and not the radiograph or computed tomography or magnetic resonance imaging. ${ }^{[4]}$
I believe that use of corticosteroids should be limited to the certain conditions that have been proven to be positively and safely influenced by them, and close follow-up is required. In general, we must not inject cortisone more often than three times a year. Too many injections increase the risk of side effects.

\section{REFERENCES}

1. Juhász K, Boncz I, Patczai B, Mintál T, Sebestyén A. Risk factors for contralateral hip fractures following femoral neck fractures in elderly: analysis of the Hungarian nationwide health insurance database. Eklem Hastalik Cerrahisi 2016;27:146-52.

2. Atik OŞ. The role of metabolomics in osteoarthritis for early diagnosis, monitoring prognosis and treatment. Eklem Hastalik Cerrahisi 2015;26:1.

3. Hannan MT, Felson DT, Pincus T. Analysis of the discordance between radiographic changes and knee pain in osteoarthritis of the knee. J Rheumatol 2000;27:1513-7.

4. Atik OŞ. Do not treat the radiograph, treat the patient! Eklem Hastalik Cerrahisi 2015;26:125.

\footnotetext{
- Correspondence: O. Şahap Atik, MD. Gazi Üniversitesi Tıp Fakültesi Ortopedi ve Travmatoloji Anabilim Dalı, 06500 Beşevler, Ankara, Turkey. Tel: +90 312 - 2025528 Fax: +90 312 - 2129008 e-mail: satikmd@gmail.com
} 